\title{
Islamophobia as Cultural Racism: The Case of Islamic Attire in Turkey
}

\author{
ALI MURAT YEL \\ Marmara University, Turkey \\ ORCID No: 0000-0002-2176-9199
}

\begin{abstract}
Grasping the various aspects of Islamophobia in Muslim societies requires much finer methods in order to decipher the intentions of the actors in distinctive life situations varying from the media to education. This article engages in a debate as to whether Islamophobia is a new type of racism, i.e., cultural, geographical, phenotypical, or Xeno-racism, and the relatively recent type that has emerged in neo-liberal states: anti-Muslim racism. In a Muslim-majority society, the 'culture' of members is fairly homogenous, so Islamophobia takes another cue, focusing on external markers, like the headscarf or beard. While anti-Muslim racism is sometimes exercised along more subtle lines of cultural difference in Muslim societies, it prevails through old-fashioned, phenotypical racism. The representation or rather misrepresentation of Islam and/or Muslims in the media can be understood as the prevailing source of antagonism between the secular and the traditionalist segments of Turkish society; indeed, Turkish media representation produces and reproduces a racialization of the majority, predominately by rendering Islam invisible, or by depicting Muslims in ways that denigrate their clothing, manners, style, and way of living across various mass media forms.
\end{abstract}

Keywords: Islamophobia, Racism, Turkey, Media Representations, Militant Laïcism

Insight Turkey 2021

Vol. 23 / No. 2 / pp. 169-189

Received Date: 09/10/2020 • Accepted Date: 08/03/2021 • DOI: 10.25253/99.2021232.10 


\section{Introduction}

slamophobia has often been treated as a new form of racism in terms of its ideological, structural, and cultural configurations. ${ }^{1}$ It is argued that cultural racism differs from phenotypical racism, which classically discriminates on the basis of skin color or particular body types. However, signifiers of Islam, like clothing, beards, names, or even different skin colors, have become new symbols of racism. This paper argues that, in a context in which phenotypical differences like skin color are not significant, other types of markers such as headscarves are employed to discriminate against, or spark, negative judgment in a similar way. If there is no difference among people in terms of their so-called racial characteristics, then slight or even insignificant differences in deportment and appearance, or even socio-economic disadvantage may be 'racialized.' In this article, I seek to develop a new framework with which to situate people who claim they have been marginalized due to their sheer appearance or assumed religiosity in Turkey. I will treat clothing, stature, education, and various social actions of individuals as if they were observable phenotypical, i.e. -physical or biochemical- characteristics determined by genetic makeup. I am suggesting that classical racism arguments lack a capacity to deal with cultural racism toward persons of the same ethnicity. I argue that it is far more difficult to detect racial discrimination in a Muslim-majority society than in other societies where Muslims are exposed to Islamophobia.

Although the term 'Islamophobia' was first defined by the Runnymede Trust, a race equality think tank in 1997, it was criticized by many scholars like Nazli Kibria in 2011 on the grounds that it would homogenize all Muslim experiences vis-à-vis ethnic-racialization. ${ }^{2}$ The race approach also ignores the gendered aspect of Islamophobia. However, in their report celebrating the $20^{\text {th }}$ anniversary of the first publication, the Trust insisted on their approach and continued to claim that Islamophobia is anti-Muslim racism. ${ }^{3}$ Instead of categorizing Islamophobia as institutionalized, new, neo with a dash, or cultural racism, I rather suggest we could stick to understanding it as a form of classical racism with phenotypical characteristics, and place emphasis on appearances rather than physiological or biological differences. I argue that the 'signifiers of Islam, like attire or beards in Ferdinand de Saussure's sense ${ }^{4}$ have become loaded contexts with racism as 'signified.' Racism is a negative treatment imagined differently under different contexts and by different subjects; we can understand Islamophobia as a form of racism experienced emotionally by victims in their daily lives.

The issue of visibility has come to occupy a particular place in the Turkish religio-political atmosphere. In Turkey, the 'headscarf question' was treated as a problem of 'visibility;' in other words, as long as women wore their headscarves within their private spaces and to some extent in public spaces like 
streets or parks, it was not considered unruly at all. However, the moment when these women wanted to wear this part of their attire in schools or state offices, the issue would suddenly become a matter of visibility; headscarves would not be allowed in the public sphere as it would threaten the laicism of the state. ${ }^{5}$ The headscarf thus signified difference, specifically religiousness as difference; keeping the 'visible sign' of the headscarf out of the public sphere meant keeping Islam out of the public sphere; as such, this exclusion maintained the dominant discourse of a subtle (or not-so-subtle), state-sponsored Islamophobia that was also, in this case, a discourse of patriarchy, as it functioned to keep Muslim women out of the public sphere.

At the time of the Turkish Republic's founding, the visibility of Muslim actors' symbols, signs, or performances, the argument went, would threaten the Republic's progress in terms of laïcité militant à la Française (French way of the militant secularism), as these symbols were considered to be the ideological antithesis to the state. The outward appearances of some Turkish citizens, like headscarves, beards, or even clothes that could be associated with rural settlements, were thought to be a threat to the Republican project. Founded on the so-called ashes of the Ottoman Empire, the young Republic was designed to be a 'modern' state like its European or Western counterparts, and the modernization project was believed to be necessarily a 'top-to-down' implementation transforming society by raising it up to the level of contemporary civilization. ${ }^{6}$

The young intellectuals of the Republic denigrated what they considered to be the backwardness and regression of Islam and, sometimes, Muslims themselves. The unstoppable decline of the Empire was attributed to the fact that the Ottoman Empire was the sole representative of the Islamic world. The founding elites, that wished to establish a new state in a Western form -despite the enmeshed religious fabric of the Turkish society- tried to separate religion from the state. Yet this separation did not take place in a form analogous to some Western states like Britain or the United States but followed the tracks of France, in which religion was subordinated to the state. Social conflict under these circumstances was inevitable, as the society with its religious values and the state officials' negative attitudes toward pious people would eventually clash. The perception of Islam as the main cause of all backwardness was the fundamental motivation of social infighting within Turkish society. The struggle went so far as to amount to a kind of racism towards a large segment of society. 
In his influential article, John Relethford remarks that the term 'race' has been used to refer to "aspects of both biological and cultural variation and has been applied to everything from geography to genes and from ancestry to language." $\mathrm{He}$ also notes that the concept is currently being used to refer to people according to their geographical settings cf., Africans, Asians, Europeans, and even some sub-continental groups like Southeast Asians. Amongst so many dissimilar and divergent usages of the term 'race', it is no surprise that it would become a convenient apparatus with which to denote and categorize Muslims, who are subject to racist discrimination on the basis of features from skin color (definitely not 'white' but sometimes 'brown' or 'dark') to craniofacial/craniometrical shape and hair color and texture. A specialist on phenotypic variation, Relethford asks the important question, "do races exist?" and responds to this fundamental question of racial studies by ascertaining that "race is culturally constructed, as all labels are, but is also based on an underlying reality of biological variation ... [and is] a culturally constructed label that crudely and imprecisely describes real variation." ${ }^{8}$ As religion and race have often overlapped, some members of religious groups have clearly been categorized as if they were easily distinguishable according to phenotypical differences like skin color. Muslim bodies all over the world are labeled and, most importantly identified, by outward appearance like their headscarves, prayercaps, beards, and clothes, which are linked to cultural differences, which in this case are cathected with an assumption of backwardness.

If race is a social construct, then all of its components, like being 'black' or 'white, are the products of this construction and consequently, the racial hierarchy determines a person's place in society on the bases of these shades. In most societies in the world, the exclusivity of 'whiteness' allows racists to implement their white social order without using pro-white terminology. For instance, Muslims in particular and Asians, in general, are viewed by some as potential threats to British society's social order, and cultural and national identity. This negative attitude has led to the creation of a new category, 'brown bodies,' which refers to erstwhile white people who had converted to Islam. In other words, a 'brown body' is like an anomalous species that combines being white and Muslim at the same time since these two characteristics, Islam and whiteness are inconceivably incompatible. ${ }^{9}$

\section{Relations and Perceptions of Race in Turkey}

In Turkey, whiteness has been associated with all the positive traits of respectability, like being modern, progressive, open-minded, having fine manners, etc. On the other hand, religiosity or piousness is equated with being backward, anti-modern, narrow-minded, radical, and reactionary. Yet, as a sociological fact, the religion of Islam has had a crucial role to play in Turkey's political, 
legal, cultural, and social spheres since the foundation of the Republic. Nonetheless, like Catholics in Northern Ireland or Jews in general, the Muslims of Turkey have been exposed to all kinds of 'religious discrimination.' Although Muslims in Turkey were and are the native people of the land, and part of the common culture, they became subject to stereotypes about foreignness and otherness. Thus, Islamophobia in Turkey does not target foreign or

Islamophobia in Turkey does not target foreign or non-Turkish groups -on the contrary, its victims are the indigenous people who have made up the bulk of the native Turkish population for generations

non-Turkish groups - on the contrary, its victims are the indigenous people who have made up the bulk of the native Turkish population for generations.

Turkey was founded on the ashes of the Ottoman Empire; it cut all its ties with that traditional entity after the declaration of the Republic in the 1920s. However, despite all attempts to reject everything assumed to be Ottoman, some people claim that certain elements of Ottoman identity persist in Turkey's contemporary national identity, such as certain traditions, customs, common history, language, and religion; and argue that these features contribute to making the nation of Turks distinct from all others as inheritors of the Ottoman Empire. This group believes that they should conserve all of these elements in order to continue to exist as a separate political entity in the world arena. However, there is another group that believes Turkey is a modern nation, different from the Ottoman Empire, that should display characteristics consistent with a modern nation-state purged all of its traditional elements and outworn customs. During the Republic's formation period, the founding elites under the leadership of Mustafa Kemal Atatürk forged a new identity and self-image for Turkey totally independent of the six-century-old Ottoman dynasty. This forged image of the Turkish national identity was built on the concepts of secularism and nationalism. ${ }^{10}$ Yet this understanding of secularism was quite problematic in the Turkish context, owing to the nature of this model. The type of laïcité implemented in France, almost in a militant fashion, understood as the total expulsion of religion from the public space was taken, adapted, and imitated by the young Turkish Republic.

The formation years of the Republic witnessed a strict separation between the Muslim faith and Turkish social, public, and political life. This historical experience was bitterly felt by virtually all segments of Turkish society in different forms, as many found themselves prohibited, excluded, hindered, or blocked from the public space, education, economic and cultural institutions, and excluded from many other social and political privileges. The majority of the Turkish people felt marginalized by the privileged minority, as Şerif Mardin 


\section{The relationship of a specific society with modernization or, more specifically, Westernization, plays an important role in the production of these Islamophobic images}

succinctly puts it in his analysis of the differentiation between the center and periphery of Turkish society. ${ }^{11}$ Nearly a century later, the early Republic's perception of secularism was challenged by the Justice and Development Party (AK Party, Adalet ve Kalkınma Partisi) governments, and another understanding of secularism began to be adopted, this time from Britain. This Anglo-Saxon type of liberal secularism, practiced in the United Kingdom and the United States, displayed an equal distance from all types of religious systems. For the majority of Turkish people, their religion is part and parcel of their national self-image.

The hostile attitude toward religion might have been more understandable in a European context, as this attitude was embraced in its historical context; however, some young Turkish students who were sent, for example, to France to receive training in engineering in order to contribute to the Ottoman Empire's military sector, were also influenced by the current debates in Parisian cafés in that period. Therefore, it was a sort of misunderstanding and miscalculation on the parts of these young Ottoman intellectuals who could not conceive the prevailing circumstances of their own society.

For European or American individuals, perhaps, religion is not a condicio sine qua non (an indispensable condition) part of their identity. However, Turkey's traditional past, with its contribution to human civilization in Turkic states, holds Islam as an inalienable part of its identity, which the staunch laïcists of modern Turkey continue to deny. Although a conservative political party, the AK Party, has been working to amend conditions for the religious segment of Turkish society since 2003, Islamophobia continues to be an important tool with which to reproduce the Turkish state's cultural laïcist hegemony over Muslims. Advances and amelioration in the political representation of Muslims who have gained greater rights should be complemented by cultural transformations that would deconstruct the dichotomy between Islam and modernity so that Islamophobia can adequately be addressed and eradicated.

It seems that the founding elites of the Turkish Republic had a particular understanding of the concepts of 'laïcism' (separation of church and state, roughly) or even 'secularism' (profane, non-religious, unclerical, and this-worldly). ${ }^{12}$ In their view, if Turkey wished to modernize, it needed to erase religion and related 
in Turkey, a country that has been attempting to realize its own modernization process for almost two centuries, the media has assumed the role of distancing the society from its roots and traditions
Westernization; anything associated with the 'East' has been excluded from modernity. ${ }^{14}$

Similarly, in Turkey, some segments of the society do not directly reject the Muslim faith itself, and instead claim that they object to certain elements of the practice of Islam, such as Arabic clothing, which belongs to other societies and cultures, and insist that they are against these elements, not Islam itself. If we were to categorize these persons as Islamophobes, they would immediately refuse such labeling; instead, they would consider themselves something like 'progressive Muslims' or 'Muslims adapted to the values of the Enlightenment.' Therefore, it would not be an easy task to go around accusing these people of attacking Islam. Yet, as ordinary Muslims on the street feel threatened by these kinds of attitudes coming from their fellow, secularized Muslims, and especially if they believe that their fundamental rights are not respected, and then we might in fact carefully consider these attitudes as Islamophobic. Despite the current, common belief in Turkey that Turkish people are in no way racist, it is obvious that they are -contrary to their historical inheritance from the Ottoman Empire- nonetheless becoming less and less tolerant of others. ${ }^{15}$

\section{Islamophobia in Contemporary Turkey}

The founding figures of the Turkish Republic distinguished themselves as being equipped with contemporary Western values and principles. They insisted that their values are part of modern democratic societies and they firmly believed that the Turkish nation could only be emancipated by adopting these 'modern values.' Yet, if any of these values were linked to some religious aspect of Turkish national identity, they would immediately oppose them in the name of modernity. This attitude is understandable during the formation years, but as Turkish society matured in terms of democratic values, especially in this age of individual rights, some groups and political forums have, also understandably, begun to resist violations of their basic rights.

For instance, nowadays there is an extra-curricular activity that could be called 'values education' in Turkish primary schools, in which children are taught some basic social and cultural values as a Muslim-majority country. Until recently, it would be a familiar news bulletin item that TV viewers would hear quite often that a school teacher had taken his/her students on an excursion that included a visit to a local mosque, or a principal of a high school had al- 
lowed a disused lower-ground room to be designated as a prayer room. These types of behaviors were once considered a potential threat to the secular Turkish Republic, as these types of mass-media products were so common that they clearly aimed at a kind of social and cultural engineering.

The Turkish -or rather, the Turkish state's- understanding of secularism needs to be reassessed, as there are alternative versions of laïcism or secularism, such as the Anglo-Saxon type of secularism, which stands at equal distance from beliefs and non-beliefs by protecting their right to exist in modern society. It can be taken as one of the successes of the AK Party that Turkish society has been in transition toward a less militant type of secularism in this century. In this regard, various steps forward have been taken, including -'Alevi Workshops' that deal with finding solutions for the problems of the Alevi minority in Turkey, and the restoration of various churches and synagogues, such as the Cathedral of the Holy Cross in Aghtamar in 2007, the Grand Synagogue of Edirne in 2015, and the Bulgarian St. Stephen (Iron) Church in 2018. The AK Party period has signaled a process of democratization and commitment to human rights in terms of the practicing of religious identities.

Despite positive developments with regard to the evolution of secularism in Turkey, religion and particularly Islam has historically been a source of anxiety. ${ }^{16}$ Recently, the government announced plans to introduce prayer rooms in public high schools to create a necessary space for anyone to practice his/ her religious duties. The long-established Islamophobic minority considers this development not as a democratic step for people to enjoy the freedom of religion, but as a destructive step against the foundations of the laicist regime. It is only natural that some people disagree with such freedom-enhancing developments for some groups. These staunch secularists express their disdain at any opportunity, as they perceive any sign of Islam, for example, women who wear the headscarf, as a threat to their existence.

While hostility toward religion often took the form of anti-clericalism in the West, a similar antagonism took the guise of opposing any type of religion and religious activities in Turkey. What is more, all religious displays were considered to be damaging to a Turkish national identity forged in a secular manner. Opposition in the Turkish case was not directed at certain aspects of the religion of Islam, but at all of the features of the religion in a wholesale manner. Talking about Islamophobia in a Muslim society might appear strange, ${ }^{17}$ but it can be understood as simply opposing anything and everything religious in the society. In other words, Islamophobia in a Muslim society is something like a blend of anti-clericalism and a specific, highly exclusive understanding of secularism.

In the Turkish case, Islam was regarded by the founding figures of the Republic as something belonging to the primordial, outmoded national identity 
that needed to be denied and marginalized in the name of modernity. In this respect, Islam became a subject of hatred that needed to be removed from society. Today, this Islamophobic treatment of religion is so pervasive and subtle that it can only be detected by paying explicit attention to the content of cultural products because the majority would immediately and emphatically refuse to acknowledge their Islamophobic tendencies.

Modern Turkish history is filled with narratives of military coups in almost every decade after the transition ${ }^{18}$ to a multi-party parliamentary system in the 1950s. Indeed, Turkey's 'military tutelage' and the coups it frequently inspired functioned in explicitly Islamophobic ways to keep religion out of the public sphere. The most recent and most memorable of these interventions occurred in $1997^{19}$ on February 28, when the military issued a series of so-called recommendations that then Turkish Prime Minister Necmettin Erbakan (the Welfare Party, Refah Partisi) had to accept. All of the 'recommendations' were related to religious issues, like the compulsory education program that prevented children from enrolling in religious high schools (Imam-Hatip) at an early age. The most influential one was the infamous ban on headscarves for university students. The Welfare Party was closed down and many of its members were banned from politics. Recep Tayyip Erdoğan, the current President of Turkey, went on to establish the Justice and Development Party that came to power immediately after the first general elections in 2002 and continues to govern the country. Apart from this 'unintended consequence' of the coup attempt of 1997, Turkish collective memory still keeps track of those events, and even today they probably play an important part in the inevitable and unstoppable success of the AK Party. In a sense, this success can be interpreted as a kind of political pushback against the Islamophobia and marginalization of the majority of the population.

One of the consequences of the 1997 military coup was that it prevented female students who wore headscarves and male students who grew beards from entering university campuses. The establishment of dress codes would be understandable and acceptable in the cases of professions that require a specific uniform, or standardized code of clothing according to the distinctive nature of the job. However, even in the cases of security officials, like soldiers or police officers, some exceptions could be applied, like wearing a headscarf under a helmet or permitting the beard of a Sikh person in the police force. However, under the hostile and militaristic style of Turkish laicism, any religious symbol was to be removed from the public sphere without any toleration. People who wished to show these symbols on their bodies would immediately become 'brown bodies' in the Turkish context. I use the metaphor of 'brown body' ere not to refer to their actual skin color but to the way they are treated in other racial contexts. I intend to utilize it for Turkish people who have been excluded from power in general. They were made 'brown' because their corporeal ap- 
pearances were the clearest visual cue to distinguish them from the rest of society. Corporeal politics has been increasingly practiced in various arenas like the media and politics, as the growing use of the photos, selfies, memes, and 'likes' of the digital age have become part of individual lives. Sadly, 'brown lives' have been widely "perceived as inherently less in worth than [those of their] white counterpart[s];"20 in the Turkish case, persons wearing the markings of Islam were considered less worthy than their secular counterparts, specifically not worthy enough to be entitled to any fundamental rights like education.

The brown body, meaning in the Turkish case, the Islamic body, then, has been racialized as being inferior to others, or even a signifier of a person who is unable to act rationally and reasonably and therefore needs to be guided by the 'Republican, secular, Kemalist whites' to reach the right path. Being subject to police brutality, these 'brown bodies' were repelled from the main gates of universities and witnessed obnoxious scenes in which some sensible people, probably acting on the urge of remorse and guilty consciousness wished to 'help' these students. The most prominent figure to become a household name in those gruesome days was Professor Fatma Nur Serter, an economist who served as Vice-Chancellor of İstanbul University during the hectic days of the so-called post-modern coup. Probably due to her maternal instincts, she rushed to release the chains of these poor Anatolian girls, to free ${ }^{21}$ them from the darkness of the Middle Ages. Although the origin is unknown, something called 'persuasion rooms' emerged to convince young 'brown bodies' to remove their headscarves in order to gain the right to attend their universities. ${ }^{22}$

Turkey is a densely populated country with a relatively young population of about 80 million. Both the youth of the country and their parents attach a lot of importance to education, particularly university education since it is seen as a key to finding employment. As in other contemporary societies, in Turkey, the education of women is extremely important to the project of creating a 'modern' generation. So, if young girls achieve success -after a substantial amount of hard work- at the university level, their accomplishment is something precious and not to be missed; therefore, putting any pressure on these young bodies would cause many unexpected consequences, potentially including alienation from their immediate families. Coercing these people to make their minds up to attend or not is an extremely heavy responsibility to place on a young person's shoulders. Exacerbating the pressure, these individuals held the belief that covering one's hair is a religious obligation in Islam; if one does not heed this com- 
This emancipation 'business' established a racialized power relationship between the enlightened seculars and the submissive, backward, religious segments of the society

mand, they are a sinner. The last point is, no matter what one believes, in any type of faith, she/he should be able to practice the requirements, and as a citizen, should be lawfully the subject of all kinds of freedoms, including religious freedom. If and when an individual is denied certain rights, simply on the basis of religion or belief -specifically on the basis of a physical marker such as hairstyle or clothing that signifies this belief- then the case would become an instance of racism, cultural racism, religious racism, and of course, Islamophobia. Nobody has any right to attempt to 'rescue' anybody from their own culture and traditions.

\section{Islamophobia and the Media}

The media plays an important role in framing the public discourses on almost everything in Turkey. As an absolute Muslim majority country, the Turkish media plays an important role, in addition to family, social customs, and education to form the perception of Islam in the country. The media image of Islam has constantly been shaped and re-shaped according to the conjuncture of contemporary politics. In a non-Muslim majority society, the image of Islam may appear in countless forms, some of them blatantly derogatory or demonized, from news coverage to implicit representation in other media products like movies and television series. In other words, Islamophobic images and texts can be utilized in various ways, both implicitly and explicitly in these societies; however, in a Muslim-majority society, the consumers of media are exposed to Islamophobia in a much subtler way. ${ }^{23}$

The relationship of a specific society with modernization or, more specifically, Westernization, plays an important role in the production of these Islamophobic images. For instance, in Turkey, a country that has been attempting to realize its own modernization process for almost two centuries, the media has assumed the role of distancing the society from its roots and traditions. As noted above, Islam has been linked to traditionalism and backwardness in Turkey and, as such, needs to be hidden from the public space as it might be a hindrance to modernization. The media try to hide the reality of Islam's existence in Turkish society by portraying Turkish people as having no religion at all. As an arm of the secular state, news bulletins are shaped by the political context and the media's assumption of being powerful or not; when the Turkish media is relatively powerful, its news bulletins depict religious people as dangerous to society and the laïque regime; at other times, like the years in which the $\mathrm{AK}$ 
Party has been in power, and in a more democratized context, certain media outlets prefer to cover religious issues in a less overtly negative manner.

Anyone who lived in Turkey just a decade ago would clearly remember the media's condescending treatment of religious people. Since religion -any religiondid not exist in media products at that time, i.e., was rendered invisible, even in the form of news coverage of a religious festival or an image of a grandmother praying with her headscarf, media consumers would infer that religion is something to be hidden from the public space. The rare representation of a pious person would only be negative. These treatments would range from making fun of taking off one's shoes before entering a house, eating dinner while sitting on the floor instead of using a table, even eating too much bread or pasta, drinking rak 1 (a traditional strong alcoholic drink) instead of consuming red or white wine, denigrating the types and qualities of people's clothes to requesting permission in workplaces or schools to perform daily religious rituals. Any argument produced to reject this view would be null, as the feelings of the subject are more important in these issues; if and when one feels humiliated by any kind of conduct, nobody could claim otherwise and say, "no, you aren't humiliated."

Soap operas occupy a great part of many television channels' prime time broadcasting all over the world. Recently, Turkish soap operas have gained huge popularity in different countries, which show them either dubbed or with subtitles. It has even been claimed that some of these soap operas might have contributed to certain social movements, especially in Muslim societies, as they depict a Muslim but at the same time modern country. However, although these soap operas have been shown in Turkey for decades, they had never explicitly included any religious aspect of Turkish social life. A comparable situation prevails in terms of advertising imagery. Advertisements are an essential tool for representing lifestyles and cultural meanings in society. In Turkey, there is a dominant advertising language that represents culture in an excessively secularized format, devoid of any signifiers that might be related to Islam or Islamic lifestyles. Even in their Ramadan advertisements, global brands such as Coca-Cola disseminate images that fail to cover the reality of Ramadan in Turkey; as if coke-drinking were an inseparable part of the daily fast-breaking diet of Ramadan. Similarly, if one watches any of Turkish television channels via satellite dish, and does not understand the language, she/he would not think that they were watching a Muslim country's TV channel by what they witness on the screen: for instance, the number of head covered TV presenters and news anchors are still not proportionate to the number of head covered Turkish women in wider Turkish society or 'experts' giving information on their specialized areas or discussing events in debate shows. In other words, the media in Turkey constitutes an ideological space where the country's long-established Islamophobia is legitimized, normalized, and perpetuated. The representations in the media in terms of the Islamophobic context occur mainly due to the he- 
gemonic structure of the media industry and its professionals. Since the early stages of the Republican era, Islamic segments of Turkish society have been systematically otherized and left out of various industries, especially the media. Despite the recent transformations in the sector in terms of the increasing participation of specialists with Islamic identities, the secular hegemony that perpetuates Islamophobia as a normative narrative persists. Hopefully, Turkey and its media will progress toward an egalitarian language and representation in the near future and manage to distance itself from Islamophobic context.

Figure 1: The Front Page of the Sözcü Newspaper (March 28, 2018)
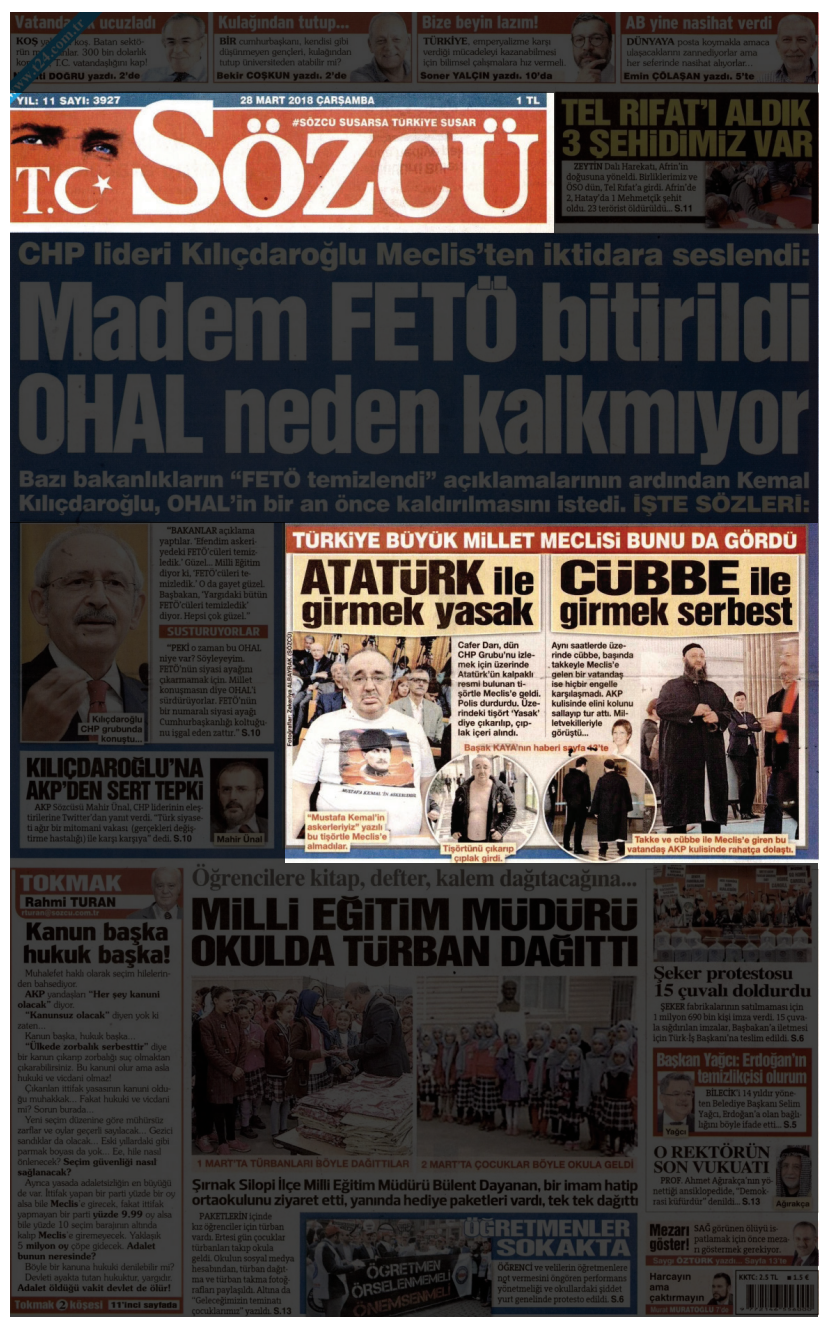

Source: Sözcü ${ }^{24}$

On any given day, visiting a newsstand kiosk anywhere in the country, one would definitely find a lot of Islamophobic content in some of the printed 
media outlets. For instance, just a casual look at one single daily newspaper like the Sözcü, one can find racist statements in the name of Kemalism, the founding ideology of the Republic. Here I need to repeat again that if the subject feels racially humiliated by any physical or symbolic action; her or his impressions must be heeded first. Since the majority of the Turkish public denies their racism, as they confuse racism with fascism, or similar political views, without being aware of their racist attitudes, it is often heard that the Turkish nation is the only one in the world free of a racist frame of mind. Readers may follow the link to see some visuals used in coverage from the front page of the Sözc $\ddot{u ̈}^{25}$ on March 28, 2018 (Figure $1)$. There is an illustration to enhance the effect of the news item about the T-shirt of a citizen who visited the Turkish Grand National Assembly the previous day. It claims (there is no clear source) that some police officers forced the citizen to remove his T-shirt, which displayed a picture of Mustafa Kemal Atatürk and an inscription -one of the political slogans of the Republican Peoples' Party (CHP, Cumhuriyet Halk Partisi)- that reads "we are the soldiers of Mustafa Kemal" beneath the picture. The second part of the news item is about another Turkish citizen who visited the Parliament on the same day dressed in a religious gown and a prayer cap with a conspicuous beard. It is said that the person wearing the T-shirt with a picture of Atatürk was not allowed to enter the building, but the person who 'obviously dressed against the values of the Republic' was allowed to freely wander around the AK Party's offices in the Turkish parliament without any obstruction. It is absolutely not known why the first citizen was denied entry (in fact, he is shown inside the CHP meeting hall in the picture) since the illustration is a very common scene at almost all CHP political rallies, and the extremely militaristic slogan has been chanted for such a long time since the first and in all the consecutive military coups in the country. In fact, military interventions have been supported by these groups against the second type of citizens, as when all the political means ran out the army would be invited to deal with the 'danger' at hand. It stands to reason that it is not acceptable to remove a T-shirt that displays Mustafa Kemal, and it needs to be investigated, and the responsible person should be punished if there was no acceptable excuse. Similarly, the second citizen, like millions of others, does not deserve to be treated like a threat to the foundations of the Republic simply because of his phenotypical appearance. The media's depiction of the incident indicates that the secularist Turkish mindset, -i.e., the point of view from which the news story is narrated- is still uncomfortable with seeing Muslim attire in Turkey's public spaces. The Kemalist segment of the society needs to learn how to live and share life together with those who differ from them. 


\section{Turkish society must come together over the question of how to be a functional democracy in which the rights of all citizens, including religious freedoms, are protected, and all members of society are treated with the same respect and dignity}

In the case reported by Sözcü, the person with apparently religious clothes is treated with phenotypical racism, as the narrator explicitly identifies his clothing as subversive, suggesting that anyone wearing such attire is considered unfit for 'modern Turkey'. This sentiment can be witnessed in many spaces in the country. If asked, the reporters or the newspaper's administration would vehemently deny the accusations of being Islamophobes, as they rather naively think that they are protecting "our land from a crippling damage coming from the past." In other words, the Kemalist members of Turkish society would prefer to keep these phenotypically dissimilar members of the society away from the public space, as if they do not exist at all.

On the front page of the daily Sözcï̈ ${ }^{26}$ on the same day, just next to the previous item, the editors of the newspaper decided to cover an event that had happened some twenty-seven days previously in Eastern Turkey. The caption reads something like this: "instead of distributing items like books, notebooks or pencils to the students, the local representative of the Ministry of National Education distributed turbans (headscarf) in the school." The implication is that the Ministry representative made a poor or, at best, misguided choice.

Going into the details of the news item, one learns that the official visited a local religious imam-hatip secondary school and gave the female students some headscarves as gifts. The next day, the students attended school with their new headscarves, and the school administration shared the photographs of both the distribution ceremony and the subsequent attendance of the students in the school's backyard in the school's social media accounts. It is true, in some of the schools in Eastern Turkey, students might need teaching materials; from time to time, there are campaigns in the country to collect these items to provide to students that need them. However, these students may also need other things, like clothes, computers, or even sometimes toys, and there is no prohibition on distributing such items in a community sharing sentiment. It is obvious from the tone of the article, however, that the specific item (headscarf) here causes a problem with the positivist mind of the Kemalist-secular elites. The way the event is covered in the paper expresses the tension between these segments of society and the greater religious tolerance in present times toward the presence of markers of religiosity in the educational system. That an item (a headscarf here) once prohibited in the schools is now being distributed by the officials seems to be something unacceptable. It must be very difficult for 
the secularists to understand that some students might need both computers (which for them represent the superior culture of modernity) and turbans (which for them represent backwardness) at the same time. It does not occur to them that a headscarved woman or a bearded man would definitely be able to use some electronic devices and create wonderful results that would be useful for both themselves and the whole society.

Such phenotypical racist attacks not only target female clothing but the religious habits of the imams, or religious clergy. As a secular country, the clergy of any religion cannot dress in their religious attire in the Turkish public sphere. They are only allowed to do so within their respective shrines. However, these habits are the easiest items with which to represent these religious figures in various media platforms, ranging from television shows to cartoons.

Figure 2: A Screenshot of the Güldür Güldür TV Show

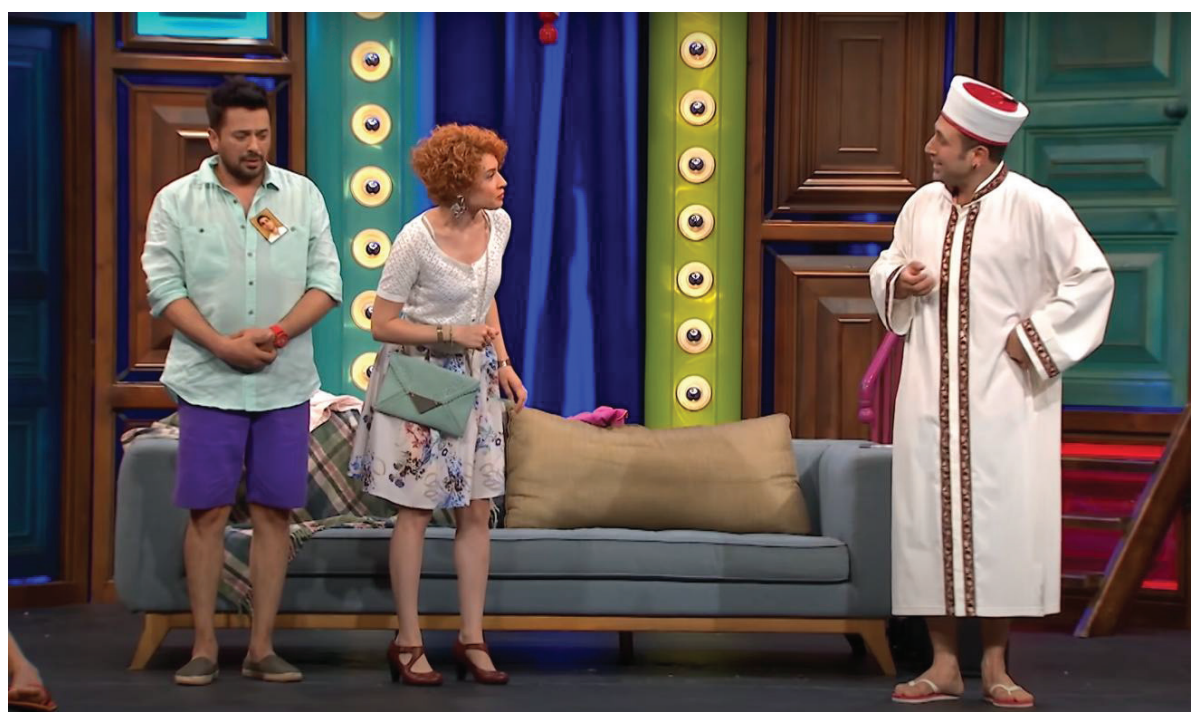

Source: Birgün ${ }^{27}$

Turkish religious authorities and a considerable number of religiously sensitive citizens have complained that a TV show called Güldür Güldür, broadcast on Show TV, portrayed an imam (obviously for comic effect) in religious garb but wearing an earring, sporting beach shorts, and slippers underneath his robe. ${ }^{28}$ Apparently, some of the viewers did not feel the sitcom program was funny at all ${ }^{29}$, as the headwear and thong slippers do not fit with each other. More significantly, an earring is considered unseemly on an imam's ear. Entertainment, or in Mikhail Bakhtin's treatment of François Rabelais's oeuvre, the carnival or carnivalesque context is embodied in the figure of the clown or fool. ${ }^{30}$ Yet, although one might satirize the society or at least some members of 
Only by ending the perpetuation of Islamophobia, can Turkey come together as a truly modern, fully democratic society

it for a short period of time, the effects last beyond the festival's day or in this case the sitcom's episode. The transition from ordinary life to grotesque popular culture is possible through laughter and exaggeration. Grotesque realism calls attention to the distinction between the 'classical body' and the 'grotesque body;' while the former is achieved and established through formal mechanisms, the latter is unfinished and created for laughter. Mocking a community's religious culture and values might be tolerated for a while in a carnivalized atmosphere, or within the invisible brackets of a television episode, but since the laughter of the carnival is universal and degrading, it eventually revolves around antagonism and hostility. Therefore, such media shows cannot be taken lightly, or solely for entertainment purposes, as their effects spill over into social commentary. That the body of an imam was made a source of laughter in a temporarily tolerated parody was actually abused to humiliate the formal structures of religion. Again, another signifier of Islam, the garb and headgear of an imam, in this case, was attacked with racist motives. One wonders whether similar treatments of other religions in an anti-clerical fashion would be possible toward, for example, a representative of Christianity or Judaism. Perhaps lack of religious knowledge about other beliefs or, what is worse, hesitation about the consequences and reactions that would come from the adherents of these faiths or political authorities would prevent the production of similar media texts. Yet, they take the liberty of mistreatment of Islam and Muslims.

\section{Conclusion}

There will likely be much more debate on the racist aspects of Islamophobia in Muslim-majority countries, and the issue may best be approached by addressing the underlying causes first. Turkey presents a unique example among many other Muslim societies in terms of its culture and traditions, particularly its history as a superpower that once governed a huge geography without being colonized at any point. The Ottoman State was exemplary in terms of treating its religious or ethnic minority subjects with tolerance and creating and maintaining a harmonious society for six centuries. However, after the demise of the Empire, or, as one might say, after losing its battle against modernity and modern colonial powers, the new nation-state was forced to accept the terms of adopting a more secularized lifestyle. Islam was at that time considered an obstacle to achieving the level of contemporary civilization. Therefore, the founders attempted to wipe out Islam from the daily lives of the people by presenting, representing, and portraying it as if it were a reactionary force. Islam, and anything that reminds people of it, was declared a public enemy; women 
were particularly singled out by their outward manifestation of dress codes. Portraying women as submissive and backward enabled the self-appointed emancipators to save and free them from their 'oppressors.' This emancipation 'business' established a racialized power relationship between the enlightened seculars and the submissive, backward, religious segments of the society. This was the general outlook taken up and reproduced by the 'owners' of the country and the consequences of this stance continue to appear in mass cultural products.

In conclusion, some individuals in Muslim-majority societies are treated differently and 'less than, 'simply because of their outward, corporeal differences; this discriminatory treatment may thus be considered a form of racism that practices, reinforces, and perpetuates Islamophobia. Nobody is born racist, but all racists pass through a certain process of learning and indoctrination to become racists. That is perhaps why all racists deny that they are racists because in the process of this indoctrination they internalize and normalize their actions. In previous centuries, racism was limited mainly to phenotypical characteristics like skin, hair, or eye color, but in today's 'age of the image', phenotypes include extensions of the body; specifically, articles of clothing that are acted upon in a racist society just as phenotypical characteristics are, in the service of 'racial bias' against those who appear different from members of the society's normative group. One of the unique features of the Turkish case is that the normative group in this instance is a distinct minority exercising judgment over and oppression of the Muslim majority whose exclusion from public life on the basis of religious markers is anything but democratic. In the coming years, Turkish society must come together over the question of how to be a functional democracy in which the rights of all citizens, including religious freedoms, are protected, and all members of society are treated with the same respect and dignity. Although much progress has been made in this direction, further attention must be paid to the representation of Muslim identities in and across various forms of media, and to investigate the assumptions behind, and the purposes of these representations. Only by ending the perpetuation of Islamophobia, even in subtle forms, can Turkey come together as a truly modern, fully democratic society.

\section{Endnotes}

1. Tariq Modood, "'Difference,' Cultural Racism and Anti-Racism," in Pnina Werbner and Tariq Modood (eds.), Debating Cultural Hybridity, (London: Zed Books, 1997), pp. 154-172; Pnina Werbner, "Essentialising Essentialism, Essentialising Silence: Ambivalence and Multiplicity in the Constructions of Racism and Ethnicity," in Werbner and Modood (eds.), Debating Cultural Hybridity, pp. 226-254; Pnina Werbner, "Folk Devils and Racist Imaginaries in a Global Prism: Islamophobia and Anti-Semitism in the TwentyFirst Century," Ethnic and Racial Studies, Vol. 36, No. 3 (2013), pp. 450-467; Louise Cainkar and Saher Selod, "Review of Race Scholarship and the War on Terror," Sociology of Race and Ethnicity, Vol. 4, No. 2 (2018), pp. 165-177. 
2. Nazli Kibria, Muslims in Motion: Islam and National Identity in the Bangladeshi Diaspora, (New Brunswick, NJ: Rutgers University Press, 2011).

3. "Islamophobia: A Challenge for Us All," Runnymede Trust, (1997); "Islamophobia: 20 Years On, Still a Challenge for Us All," Runnymede Trust, (2016), retrieved February 15, 2018, from https://www.runnymedetrust.org/blog/islamo phobia-20-years-on-still-a-challenge-for-us-all.

4. Ferdinand de Saussure, Course in General Linguistics, translated by Roy Harris, (London: Duckworth, 1993).

5. Nilüfer Göle, Islam and Secularity: The Future of Europe's Public Sphere, (Durham and London: Duke University Press, 2015) pp. 7-8.

6. Feroz Ahmad, Turkey: The Quest for Identity, (Oxford: Oneworld, 2003); Sibel Bozdoğan, Modernism and Nation Building: Turkish Architectural Culture in the Early Republic, (Seattle and London: University of Washington Press, 2001); Ayşe Kadıoğlu, "The Paradox of Turkish Nationalism and the Construction of the Official Identity," in Sylvia Kedourie (ed.), Turkey: Identity, Democracy, Politics, (London: Frank Cass, 1996), pp. 177-193; Şerif Mardin, The Genesis of Young Ottoman Thought, (İstanbul: Illetişim Yayınları, 2003); Erik-Jan Zürcher, Turkey: A Modern History, $3^{\text {rd }}$ ed., (London, New York: I. B. Tauris, 2004).

7. John H. Relethford, "Race and Global Patterns of Phenotypic Variation," American Journal of Physical Anthropology, Vol. 139, No. 1 (February 18, 2009), p. 16.

8. Relethford, “Race and Global Patterns of Phenotypic Variation,” p. 20.

9. Tina G. Patel, Race and Society, (London: Sage Publications Ltd, 2017).

10. Dox Waxman, "Islam and Turkish National Identity: A Reappraisal," Turkish Yearbook of International Relations, Vol. 30, (2000), pp. 1-22.

11. Şerif Mardin, "Center-Periphery Relations: A Key to Turkish Politics?" Daedalus, Vol. 102, No. 1 (1973), pp. 169-190.

12. Ahmet Demirhan, Modernlik, (İstanbul: Insan Yayinlari, 2004).

13. James L. Heft, A Catholic Modernity? Charles Taylor's Marianist Award Lecture with responses by William M. Shea, Rosemary Luling Haughton, George Marsden, and Jean Bethke Elshtain, (New York: Oxford University Press, 1999).

14. Katerina Dalacoura, "'East' and 'West' in Contemporary Turkey: Threads of A New Universalism," Third World Quarterly, Vol. 38, No. 9 (2017), pp. 2066-2081.

15. Umut Uzer, "Racism in Turkey: The Case of Hüseyin Nihal Atsız," Journal of Muslim Minority Affairs, Vol. 22, No. 1 (2002), pp. 119-130.

16. One of the oldest newspapers in Turkey, the Cumhuriyet daily, which was established on the orders of Kemal Atatürk, was formerly a Republican newspaper that attempted to instill the newly-established state's secular values in people in the beginning. However, after the multi-party period in the 1950s and during the Cold War, it adopted a kind of leftist-social-democratic stance; whenever a conservative-led government came to power, the newspaper would start a campaign to warn people with a highly provocative slogan of "Are You Aware of the Danger/Threat?" inscribed in Arabic-looking Latin letters, implying that Turkey would be hijacked from modern values and dragged back into the darkness of the Middle Ages.

17. It means that Islam is not a part of the social identity of the whole nation, whether Muslim or not.

18. Kemal H. Karpat, Turkey's Politics: The Transition to a Multi-party System, (Princeton, N.J.: Princeton University Press, 1959).

19. "Timeline: A History of Turkish Coups," Al Jazeera, (April 2012), retrieved March 28, 2018, from https:// www.aljazeera.com/news/europe/2012/04/20124472814687973.html.

20. Somayra Ismailjee, "What Is a Brown Body Worth?" Eureka Street, Vol. 26, No. 2 (January 2016), retrieved from https://www.eurekastreet.com.au/article/what-is-a-brown-body-worth, pp. 50-52.

21. Similarly, some White Western feminists try to 'save' or 'liberate' their sisters who remain under the oppression of dark ages in backward geographies; these 'enlightened' women do not need to learn 
what these 'native' or 'brown' women want in their own lives. See, Lila Abu-Lughod, Do Muslim Women Need Saving? (Cambridge, MA: Harvard University Press, 2013), and Gayatri Chakravorty Spivak, "Can the Subaltern Speak?" in Patrick Williams and Laura Chrisman (eds.), Colonial Discourse and Post-Colonial Theory: A Reader, (Hemel Hempstead: Harvester Wheatsheaf, 1994), pp. 90-105.

22. Yusuf Selman İnanç, "Feb. 28: A military Coup Never to Be Forgotten," Daily Sabah, (February 27, 2014), retrieved March 28, 2018, from https://www.dailysabah.com/politics/2014/02/28/feb-28-a-military-coup-never-to-be-forgotten.

23. Ali Murat Yel and Alparslan Nas, "Insight Islamophobia: Governing the Public Visibility of Islamic Lifestyle in Turkey," European Journal of Cultural Studies, Vol. 17, No. 5 (2014), pp. 567-584.

24. The Front Page of Sözcu Newspaper, Sözcü, No. 3927 (March 28, 2018) retrieved April 18, 2021, from https://www.sozcu.com.tr/2018/gundem/ataturk-tisortu-giydi-meclise-giremedi-2314628/.

25. The Front Page of Sözcu Newspaper, Sözcü, No. 3927.

26. The Front Page of Sözcu Newspaper, Sözcü, No. 3927.

27. Birgün Newspaper's website (March 14, 2021), retrieved April 18, 2021, from https://www.birgun. net/haber/imamlar-guldur-guldur-show-yayindan-kaldirilsin-337524.

28. "İmamlardan 'Güldür Güldür Kaldırılsın' Talebi: 'Alçak Herifler,' Zavallı Program...' Cumhuriyet, (March 14, 2021), retrieved March 15, 2021, from https://www.cumhuriyet.com.tr/haber/imamlardan-guldur-guldur-kaldirilsin-talebi-alcak-herifler-zavalli-program-1820623.

29. For example, the Union of Turkish Religious Foundation (Türkiye Diyanet Vakıf-Sen), an entity that had been established to support the ervices of the Directorate of Turkish Religious Affairs filed a complaint to the Radio and Television Supreme Council (RTÜK), Yeni Şafak Newspaper website (March, 14, 2021), retrieved March 15, 2021, from https://www.yenisafak.com/hayat/guldur-guldurden-cirkin-skecimami-parmak-arasi-terlik-ve-kupeyle-sahneye-cikardilar-3603647.

30. Mikhail M. Bakhtin, Rabelais and His World, translated by Helene Iswolsky, (Bloomington: Indiana University Press, 1984); Simon Dentith, Bakhtinian Thought: An Introductory Reader, (London: Routledge 1995). 


politicstoday.org

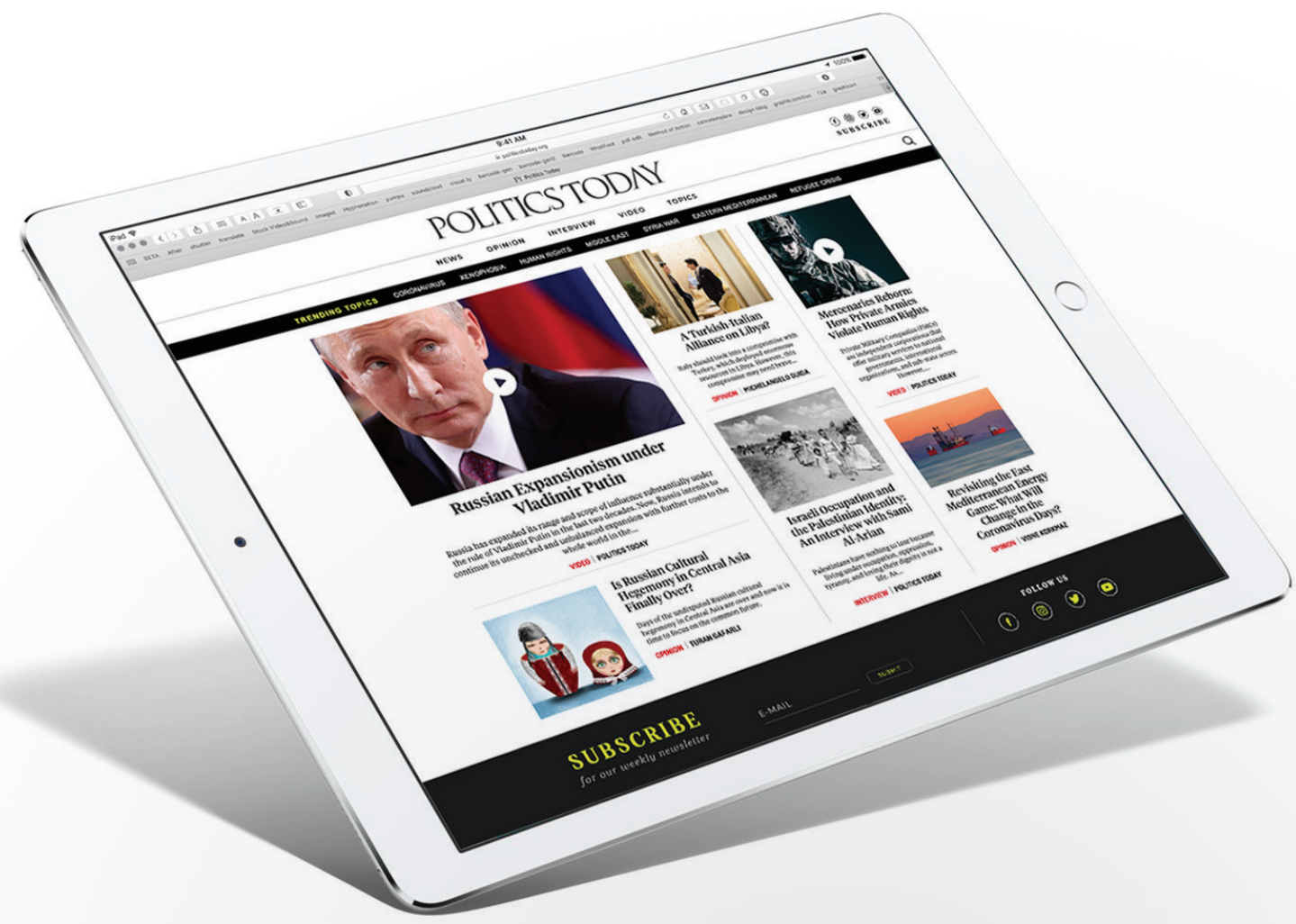

Are you concerned with the contemporary world,

where human rights are violated, human dignity is trampled, international order is indifferent to any principle or value, and the might silences the right?

Then, follow and join Politics Today in its endeavor to understand and analyze the changing nature of international politics.

\section{POLITICS TODAY}

